\title{
Research on the Performance of Industrial Innovation of Small and Medium-sized Listed Companies in China
}

\author{
Tingfa Zhang, a* \\ ${ }^{1}$ Research Department, Qilu Normal University, China \\ a ztfsdu2011@163.com,
}

\begin{abstract}
Keywords: Innovation performance; innovation spillover effect; industry innovation; Small and Medium-sized Listed Companies
\end{abstract}

\begin{abstract}
Innovation is the real source of economic growth, and industrial innovation is systems integration of the technological innovation, product innovation and market innovation, which is the basic determinant of national competitiveness. This paper constructs an analytical framework that includes variables such as innovation spillover effect, innovation input, innovation output and industrial effect. Through the investigation and analysis of the innovation activities of China's small and medium board listed companies in 2006, 2007 and 2008, this paper examines the innovation performance and the above factors. The results show that there is a significant positive correlation between firm performance and innovation input and innovation output, but there is no significant correlation with the innovation environment and industry background such as government support and innovation opportunity, and the spillover effect is significant Negative correlation, and innovation human capital investment, company age, company $\mathrm{Q}$ value also showed a negative correlation.
\end{abstract}

\section{Introduction}

When the world is still struggling in the financial crisis, we see the value of innovation: innovation is an important driving force to promote sustained economic growth, out of the shadow of the crisis. Since the introduction of Schumpeter's theory of innovation, the impact of innovation on economic growth has become increasingly important to economists. The general view is that innovation is an important endogenous variable in economic growth (Baumol, 2002, 2007; Malerbaand Brusoni, 2007; Peters, 2008 ). Baumol (2002) emphasizes that innovation is the real source of unprecedented growth in capitalist economy, while independent innovation small businesses and large high-tech enterprises are driving two wheels of innovation.

\section{Industrial innovation}

The meaning of industrial innovation. . Schumpeter argues that the essence of innovation is industrial mutation or creative destruction, and creative destruction is the fundamental driving force of economic growth (Schumpeter, 1934). Since the birth of Schumpeter's theory of innovation, the theory and practice of innovation have made great achievements in the world, such as the national innovation system, the regional innovation system and the construction of the department, industry and enterprise innovation system. Schumpeter's innovation is actually the concept of industrialization that is now popular among our public opinion circles. Industrialization is essentially the new combination of production factors, that is, the process of technological innovation into the process of goods, that is, the process of industrial innovation. Therefore, we can say that Schumpeter's innovative concept is consistent with the connotation of industrial innovation.

This paper argues that the concept of industrial innovation is more reasonable and easier to study. It can be said that industrial innovation is the system integration of technological innovation, product innovation and market innovation. It is the breakthrough of enterprises to break through the structure of the industry. The use of technological innovation, product innovation, market innovation or 
combination innovation to change the existing industrial structure or The process of creating a new industry is what Schumpeter calls the process of industrial mutations or creative destruction ( $\mathrm{Lu}$ Guoqing, 2002).

Research Progress at Home and Abroad. A large number of empirical studies have shown that innovation is significantly positively correlated with firm performance and firm competitiveness (Peters, 2008), but there are also findings that R \& D inputs are weakly related to firm performance and that innovation can not explain the growth of all firm productivity (Griliches, 1994). Peters (2008) conducted a systematic investigation into the innovation performance of German enterprises. The basic conclusion is that the growth of labor productivity and labor productivity is positively correlated with product innovation, and process innovation and firm performance are not conclusive. The elasticity coefficient of intellectual capital production in German manufacturing enterprises is about 0 . 04 , slightly lower than the output elasticity coefficient of R \& D capital stock.

With the growth of the new economy, there have been three new developments in the field of innovative economics, which are the effects of diffusion effects on productivity, the different forms of $\mathrm{R} \& \mathrm{D}$ cooperation, and the role of innovation in innovation when innovation is increasing (Sena, 2004 ). Diffusion effect has become a hot spot in foreign innovation research. In the endogenous growth model, technology spillovers or R \& D spillovers are commonly regarded as important factors (Grossman and Helpman, 1991).

Bernstein \& Nadiri $(1988,1991)$ found that the diffusion effect is statistically significant for all industries in the United States, as long as companies in different fields are technically similar or share the same technical basis, The diffusion effect arises; they find that in all industries the diffusion effect can result in a variable cost reduction and an increase in output, leading to a decline in product prices. Jaffe's (1986, 1989) conclusion shows that the company's productivity growth is positively related to its own R \& D and research and development in the same technical field close to its company. Aiello \& Cardamone (2009) studied panel data from 1203 Italian manufacturers in 1998-2003. It was concluded that the spillover effects of $\mathrm{R} \& \mathrm{D}$ were positively correlated with firm performance. In summary, a large number of empirical studies have shown that R \& D spillovers have a positive impact on firm production (Griliches, 1991; Wieser, 2005; Aiello and Cardamone, 2009).

In recent years, some domestic scholars have begun to pay attention to the spillover effect of innovation. Long Zhihe and Cai Jie (2008) have made empirical research on the knowledge spillover effect of Chinese industrial industry on the basis of industry data. Wei Shouhua et al. (2009) applied panel data to Yangtze River Delta Regional high-tech industry innovation performance was studied. On the whole, the domestic research on enterprise innovation is basically based on the questionnaire survey and the macroscopic industry level, and the research on the innovation performance of industrial innovation, especially the micro enterprise level, is basically blank. This paper tries to make an empirical analysis on the innovation performance of small and medium-sized listed companies in China's industrial innovation, which is the most active, the most successful and influential group in China's industrial innovation. The specific research methods are based on the international microSubject method. The main reason for selecting small and medium-sized board companies as research samples is that small and medium-sized enterprises, especially small and medium-sized listed companies are active activists and winners of industrial innovation, are the leaders of the industry and the pioneer of industrial innovation. As Baumol (2007) Said that small businesses (which are defined as less than 500 employees ) basically monopolize innovative activities that have a revolutionary breakthrough.

\section{The Performance of Industry Innovation and Its Measurement}

\section{Model Design.}

The innovation process itself has a Blackbox nature, which has been plaguing people's research on innovation performance. The general conclusion is that $\mathrm{R} \& \mathrm{D}$ has a positive correlation with Productivity, and R \& D (Process-related R \& D) is more conducive to productivity than product R \& 
D (Product-related R \& D) (Griliches and Lichtenberg, 1984). But Créponetal (1998) proposed the CDM model is effective in overcoming the black box confusion of the innovation process. The CDM model applies the innovation input, innovation output and productivity index to the same model for the first time, and uses CIS (CommunityInnovationSurvey) data to realize the efficiency of product innovation and process innovation through knowledge production function. Lo ǒ f \& Heshmati (2002) has modified the CDM model and replaced R \& D inputs with innovative inputs (Peters, 2008). Again, innovation is particularly a feature of public goods that has the characteristics of public goods. Recent studies have shown that traditional approaches generally underestimate the return on R \& D activities, mainly due to the neglect of the spillover effects of R \& D activities (Mairesse and Mohnen, 2005; AielloandCardamone, 2009). Aiello \& Cardamone (2009) based on the above research on the CDM model has been improved, the establishment of a new model with innovative spillover effects.

\section{Calculation of Spillover Effect.}

According to the results of the regional innovation theory, the spillover effect of an industrial innovation activity is related to the influence of the industry itself. The most important external environmental factors are the influence factors of the area where the innovation activity occurs, such as in the industrial cluster The innovation spillover effect should be far greater than the innovation spillover effect of a single enterprise, so the simple spatial distance can not fully reflect the innovation spillover effect. In view of the actual situation of China and the possibility of data acquisition, combined with Zhao Yanyun et al. (2009) regional innovation research results, the geographical consistency index of spillover effect is used to replace the regional innovation radiation ability index in China's regional innovation capability evaluation index system, The company's technical similarity is measured by industry similarity and industry impact factors (see Liu et al., 2009). So that the following formula can be used to calculate the spillover effect of a firm's industrial innovation:

Spill $_{i t}=i$ Enterpriseindustry influence coefficien $\mathrm{t} * i \mathrm{I}$ Innovative Radiation Coefficien $\mathrm{t}$ in Region $* \mathrm{CT}_{\mathrm{it}}$ Where Spill denotes the innovation spillover effect, CT denotes the innovation input, i denotes the company, $t$ denotes the time.

Index Selection and Model. .

Assuming that the scale returns are constant, the following model is obtained in conjunction with the above selected indicators. The meanings of the indicators in the model are shown in Table 1.

$$
\begin{aligned}
& \text { LnY }=\alpha_{0}+\alpha_{H} \text { Higntech }+\alpha_{p} \text { LnPatent }+\alpha_{K} \text { LnK }+\alpha_{L} \text { LnL }+\alpha_{A} \text { LnAge }+\alpha_{c f} \text { Lncash }+ \\
& \alpha_{Q} \text { LnQ }+\alpha_{I} \text { LnInnote }+\alpha_{E} \text { LnExp }+\alpha_{S} \text { LnSpill }+\mu
\end{aligned}
$$

All sample data from WIND information, the specific source is a listed company's prospectus, annual reports and other publicly disclosed information, industry information from the Statistical Yearbook of China Science and Technology , China High Technology Industry Statistical Yearbook, 2007 industrial enterprises (2008), the innovation behavior itself is endogenous, the calculation method using Stata software for the above model for 3sls regression calculation. 
Table 1 meaning of each indicator

\begin{tabular}{l|l}
\hline \multicolumn{1}{c|}{ indicator } & \multicolumn{1}{c}{ meaning } \\
\hline Main profit(Y) & $\begin{array}{l}\text { The company's main business profits, business performance and innovative } \\
\text { performance of the comprehensive indicators of reflection }\end{array}$ \\
\hline Q value & (Total market value + value of preferred stock + liabilities) / total assets \\
\hline high-tech enterprises ( HighTech) & 1 for high-tech enterprises, 0 for non-high-tech enterprises \\
\hline Number of patents ( Patent) & The number of patents granted by the enterprise in that year \\
\hline Total assets ( K) & The company 's total assets on December 31 each year \\
\hline Innovation input ( CT) & Company annual R \& D investment \\
\hline $\begin{array}{l}\text { The proportion of employees above the } \\
\text { level ( L) }\end{array}$ & $\begin{array}{l}\text { The company on December 31 each year more than the number of employees in } \\
\text { the proportion of the total number of employees }\end{array}$ \\
\hline Company age ( Age) & The company was established until the end of the year \\
\hline Net cash flow ( Cashfloat) & $\begin{array}{l}\text { The company's operating net cash flow reflects the internal reliability of } \\
\text { inanti-n fwnd. }\end{array}$ \\
\hline Government support ( Innoe) & $\begin{array}{l}\text { The proportion of government funds invested in the industry, Reflecting the } \\
\text { efforts of innovation by the support }\end{array}$ \\
\hline $\begin{array}{l}\text { Sales of new products/total sales revenue } \\
\text { revenue revenue ( Innoop) }\end{array}$ & $\begin{array}{l}\text { The industry's new product sales revenue accounted for the proportion of total } \\
\text { sales revenue, Engaged in innovative industry opportunities }\end{array}$ \\
\hline $\begin{array}{l}\text { New product exports / total sales revenue } \\
\text { (Exp) }\end{array}$ & $\begin{array}{l}\text { The proportion of the industry's export earnings to total sales revenue, } \\
\text { Representing the innovative export learning effect }\end{array}$ \\
\hline $\begin{array}{l}\text { Spillover value ( Spill) } \\
\text { Regional innovation radiation capacity * industry correlation coefficient } * \text { sample } \\
\text { company's innovation input }\end{array}$ \\
\hline
\end{tabular}

All sample data from WIND information, the specific source is a listed company's prospectus, annual reports and other publicly disclosed information, industry information from the Statistical Yearbook of China Science and Technology, China High Technology Industry Statistical Yearbook, 2007 industrial enterprises (2008), the innovation behavior itself is endogenous, the calculation method using Stata software for the above model for 3 sls regression calculation.

\section{Empirical Analysis and Conclusions}

The model calculation results are shown in Table 2.

Table 2 Model calculation results

\begin{tabular}{|c|c|c|c|}
\hline & 2006 year & 2007 year & 2008 year \\
\hline Hightech & -0.4337948 & -0.2198724 & -0.1953138 \\
\hline LnPatent & 0.1947377 & 0.1591831 & 0.2348463 \\
\hline LnCT & 0.7022933 & 0.6742096 & 0.7355861 \\
\hline LnL & $-0.0686195 *$ & -0.3831923 & $-0.1547262 *$ \\
\hline LnAge & $0.193946 *$ & $-0.3478484 *$ & $-0.178549 *$ \\
\hline LnQ & -0.3830674 & -0.0798297 & -0.2586368 \\
\hline LnInnoe & -0.0006401 & -0.0231823 & -0.0256858 \\
\hline LnInnoop & -0.1127058 & 0.0119955 & 0.0660273 \\
\hline LnSpill & -0.3150753 & $-0.3730302 *$ & -0.4870095 \\
\hline R-squared & 0.6730 & 0.5941 & 0.4727 \\
\hline chi-squared for equation & 55.57 & 64.40 & 55.58 \\
\hline Sample & 27 & 44 & 62 \\
\hline
\end{tabular}


From the results in Table 2, we can see that the innovation performance of small and medium-sized board listed companies has a significant positive correlation with innovation input (CT) and innovation (Patent) two indicators, basically through $1 \%$ significance test, innovation performance and innovation input (CT) correlation coefficient reached 0.7 , is the highest of all factors. This means that increasing investment in innovation is still the basic path to enhance the performance of small and medium-sized board companies, but also the internal driving force of sustained growth of enterprises, which is consistent with the traditional innovation economics point of view.

First, from the test results, small and medium-sized board companies in the high-tech enterprises (Hightech), government support (Innoe) and innovation opportunities (Innoop) and innovation performance (Y) no significant correlation between, especially the first two indicators And innovation performance also showed a negative correlation between.

Second, the results show that the innovation performance and the spillover effect (diffusion effect) of the small board listed companies have a significant negative correlation with Aiello \& Cardamone (2009) on the Italian firm.

In addition, the innovation performance of small and medium-sized board listed companies has a negative correlation with the innovation human capital investment (L), company age (AGE), firm Q (industrial effect), and the first two factors have passed the significant test.

\section{References}

[1] K Parikh. Sustainable development and low carbon growth strategy for India, J. Energy, Vol.40 (1994) No.1, 31-38.

[2] Anne B., John P. U., Henning M. and Helle N..The Effect of Financial Factors on the Performance of New Venture Companies in High Tech and Knowledge-Intensive Industries: An Empirical Study in Denmark, International Journal of Management, (2003) No.12, 535-547.

[3] Gary D. Resources of the firm, Russian high-technology startups, and firm growth. Journal of Business Venturing, (2002) No.17, 533-576.

[4] M. Kamil K., Dolun Ö., and Onur Ö.. Growth Plans of Small Businesses in Turkey: Individual and Environmental Influences. Journal of Small Business Management, Vol.44 (2006) No.1, 114-129.

[5] Thorsten B, Asli D and Vojislav M. Financial and Legal Constraints to Growth: Does Firm Size Matter? The Journal Of Finance, (2005) No.1, 137 171.

[6] Rhee, J., Park, T., Lee, D. H. Drivers of Innovativeness and Performance for Innovative SMEs in South Korea: Mediation of Learning Orientation. Technovation, Vol.30 (2010 No.1, 65-75.

[7] Lǒ ǒ f, H. and Heshmati, A. Knowledge Capital and Performance Heterogeneity: A Firm Level Innovation Study, International Journal of Production Economics, Vol.76 (2002) No.1,61-85.

[8] Mairesse, J. and Mohnen, P. The Importance of R \& D for Innovation: A Reassessment Using French Survey Data, Journal of Technology Transfer, Vol.30 (2005) No.12, 183-197.

[9] Sena, V. The Return of the Prince of Denmark: a Survey on Recent Developments in the Economics of Innovation, Economic Journal, Vol.114 (2004), No.6,312-332.

[10] Wieser, R. , 2005, Research and Development Productivity and Spillovers: Empirical Evidence at the Firm Level, Journal of Economic Survey, (2005) No.19, 587-621. 